\title{
The Effect of Using the Nitrogen in Automotive Tires on the Ride Comfort
}

\author{
Prof. Ibrahim L.M. Ahmed ${ }^{1}$, Prof. Essam M. Allam², Dr. Khaled Abd Elwahed Kamal El Deen ${ }^{3}$, \\ Hassan B. Ibrahim ${ }^{1}$ \\ ${ }^{1-3}$ Automotive Technology Department, Faculty of Industrial Education, Helwan University, Cairo, Egypt \\ ${ }^{2}$ Automotive Engineering Department, Faculty of Engineering in Mataria, Helwan University, Cairo, Egypt
}

\begin{abstract}
Nitrogen as an inflation gas for passenger car and light truck tires use is widely available commercially. Consumers are confronted with a bewildering selection of offerings, and suppliers tout the purity of their nitrogen generation systems and the effectiveness of using the gas in place of air. This paper will examine a number of issues that are key to nitrogen inflation. The first is the initial inflation of the tire with air. Since there is always some nitrogen in the tire due to the bead seating process, the inflation of a tire with nitrogen typically is done using a number of inflation and deflation cycles. The phenomenon of nitrogen uses as an alternative to air in vehicle tires without any definite information about this phenomenon. also heard that it causes many problems for tires and vehicles because they are gas and not air. Moreover, there are many problems that occur while driving with tires inflation with air. Therefore, the present research has been carried out to investigate experimentally to test the use of nitrogen in vehicle tires and their effect on ride comfort and vehicle performance. The experimental results showed that at reduced tire pressure, the air is better than Nitrogen, especially at high speeds. The nitrogen inflation reduces vehicle vibration at flat roads. Finally, it is concluded that Nitrogen is good inflating fluid for all conditions at the ideal tire pressure.
\end{abstract}

Keywords: Nitrogen, Frequency, Acceleration.

\section{INTRODUCTION}

In recent years, the number of car accidents increased significantly, one of the causes of these accidents is the lack of tire's air pressure. Road traffic accidents are a major health hazard. The ensuing trauma has increased in direct proportion to the increase in the number of road vehicles. The increase in living standards in Egypt in the last few decades has brought with it dramatic changes to the lifestyle of people living in this country. One of these changes is the huge increase in the number of registered motor vehicles according to the statistics recorded for traffic management. Recently, the phenomenon of using nitrogen as an alternative to air at vehicles' tires has emerged without any confirmed information about such phenomenon at the work market. Most recently in Egypt, we have heard about providing tires with nitrogen, and how nitrogen makes tires' pressure constant and movement of vehicle smooth and flexible, especially at bumps and many other benefits. We have also heard that it causes many problems to tires and vehicles as it is a gas and not air. Moreover, there are many troubles which happen during driving vehicles with air-filled tires. Is all information said about nitrogen is true?!! Much has been learned about Nitrogen gas and air design parameters and nitrogen inflation technology in the LAST few decades. Some of this knowledge have been reviewed which lead us in this study. such as the effect of nitrogen inflation on vehicle tire The Benefits of Using Nitrogen, effect of using the nitrogen in automotive tires on the ride comfort. Based on the above, this study aims to use nitrogen at vehicles' tires and its influence on passengers' comfort and vehicle's performance.

\section{DESIGN OF TEST RIG SYSTEM}

In this research, a suspension system of quarter car test rig is designed and constructed at Department of Automotive Technology Laboratory, Helwan University, to study and develop the effect of nitrogen inflation use in automotive tires on the ride comfort. The test rig described here is designed and constructed to investigate the performance of the Conventional suspension system (torsion bar and shock absorber) at different. The test rig System Can be used to study the following, 
Effect of vehicle load on the ride comfort, Effect of tire speed on the vehicle vibration, Effect of the tire inflation pressure on the ride comfort, Effect of type of gas filling tire on the ride comfort. And Effect of height of the hump vehicle vibration and ride comfort.

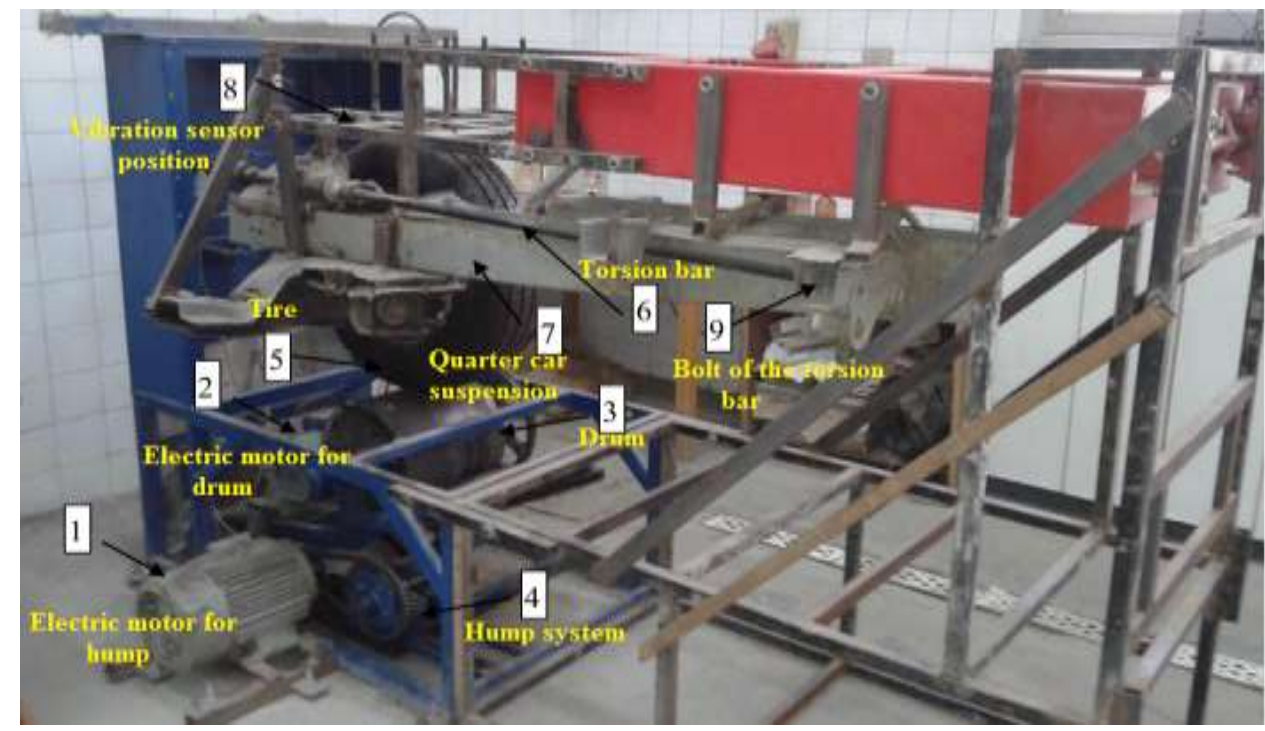

Figure 1. Photo of Torsion bar test rig.

To simulate the hump, road effect, the drum tire has the freedom to move up and down direction by using a 5 HP electric motor via connecting rod attached to the drum tire. Electric motor speed can be controlled by inventor device to change the hump position. The height of the hump can be changed by using disc has some holes in certain position and rotates by the electric motor as shown in Photo. The big end of the connecting rod connects to disc hole and the other attached to the drum. The height of the hump is controlled by changing the position of the contact point of the connecting rod end to the holes in the disc, which consists of an Electrical motor, Chain, Drum and Connecting rod. The exciter is designed to give excitation amplitudes from 50 to $80 \mathrm{~mm}$. In addition to, Power Unit, Inverter Fuji, Mechanical velocity Description, Inverter Toshiba, The accelerometer, Data Acquisition, Digital tachometer, Tire Pressure Gauge and Nitrogen Inflation device

3. Effect of tire speed on the vehicle vibration, pressure $55 \mathrm{psi}$ and $\mathrm{MS}=400 \mathrm{~kg}$.

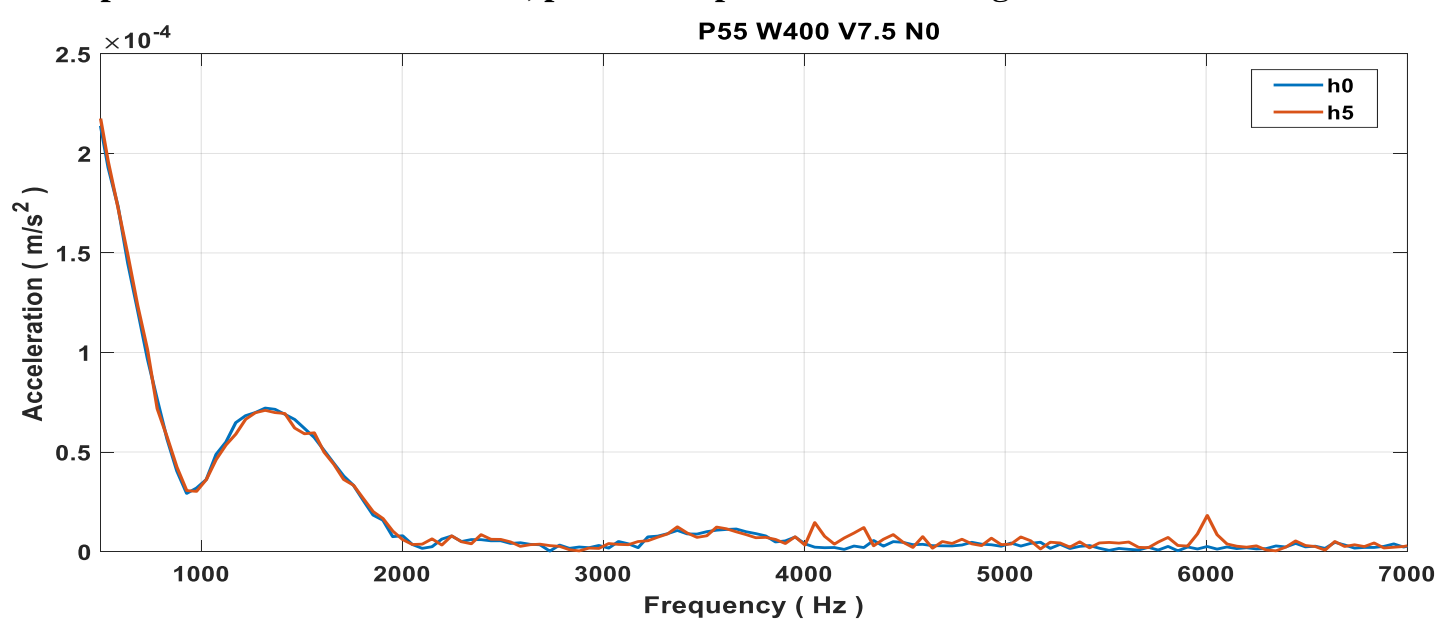

(a) Vehicle acceleration versus frequency without $/$ with speed hump, pressure $55 \mathrm{psi}, \mathrm{Ms}=400 \mathrm{~kg}$, at $7.5 \mathrm{~km} / \mathrm{hr}$. speeds, nitrogen zero\% 


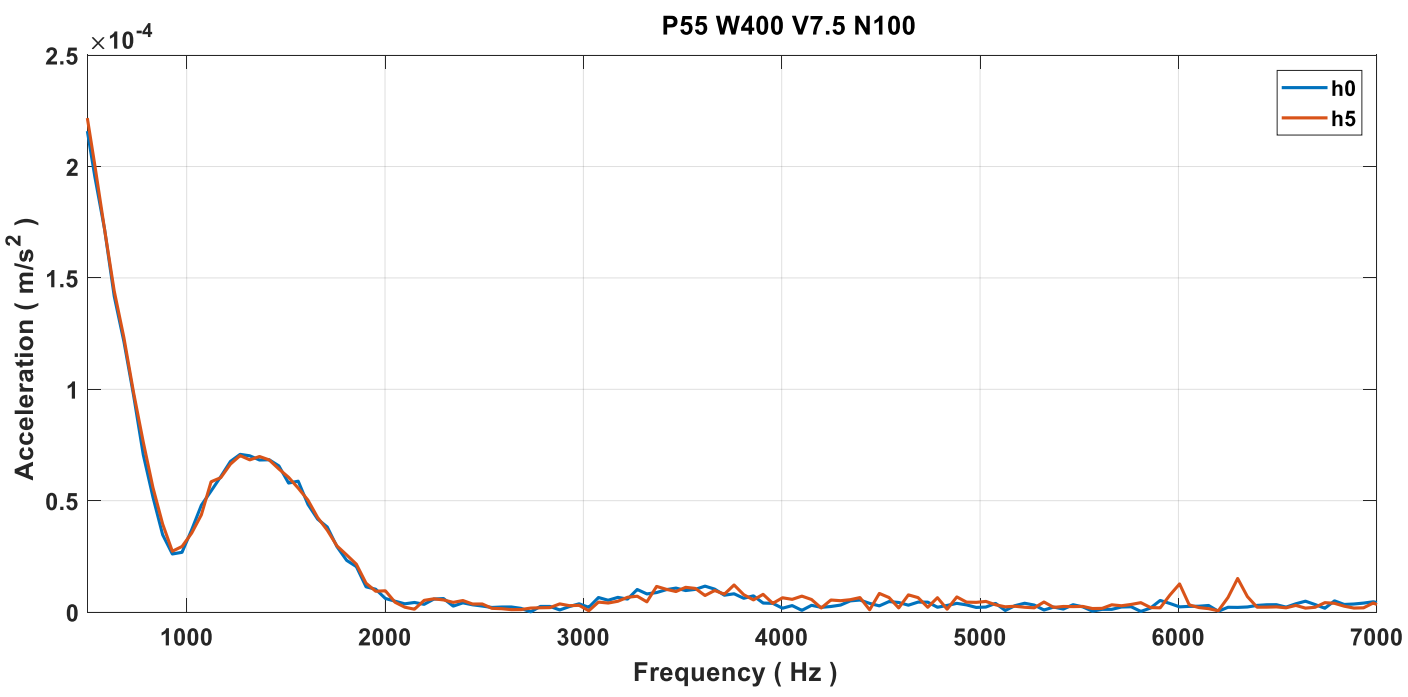

(b) Vehicle acceleration versus frequency without / with speed hump, pressure $55 \mathrm{psi}$ MS=400 $\mathrm{kg}$ at $7.5 \mathrm{~km} / \mathrm{hr}$ speeds and nitrogen $100 \%$

Figure -2. Vehicle acceleration versus frequency without/with speed hump, pressure $55 \mathrm{psi}$ and $\mathrm{Ms}=400 \mathrm{~kg}$, different tire speeds.at nitrogen zero $\%$, nitrogen $100 \%$.

Table 1. Experimental results of r.m.s for pressure 55psi, sprung mass weight of $400 \mathrm{~kg}$ and Air (N0\%), nitrogen (N100\%)

\begin{tabular}{|l|l|l|l|l|}
\hline \multicolumn{3}{|c|}{ Height speed hump $(\mathrm{mm})$} & h0 (0) & h5 (50) \\
\cline { 2 - 6 } $\begin{array}{l}\text { Bir } \\
\text { Body vertical acceleration }\left(\mathrm{m} / \mathrm{s}^{2}\right)\end{array}$ & $\begin{array}{l}\text { Nitrogen } \\
(100 \%)\end{array}$ & $\begin{array}{l}\text { Air } \\
(\mathrm{N} 0 \%)\end{array}$ & $\begin{array}{l}\text { Nitrogen } \\
(100 \%)\end{array}$ \\
\hline Body vertical acceleration $\left(\mathrm{m} / \mathrm{s}^{2}\right)$ at $\mathrm{V} 2.5 \mathrm{~km} / \mathrm{hr}$ & 0.036765 & 0.036530 & 0.037279 & 0.037200 \\
\hline Body vertical acceleration $\left(\mathrm{m} / \mathrm{s}^{2}\right)$ at $\mathrm{V} 5 \mathrm{~km} / \mathrm{hr}$ & 0.037546 & 0.037162 & 0.037866 & 0.037458 \\
\hline Body vertical acceleration $\left(\mathrm{m} / \mathrm{s}^{2}\right)$ at $\mathrm{V} 7.5 \mathrm{~km} / \mathrm{hr}$ & 0.037430 & 0.037000 & 0.037850 & 0.037400 \\
\hline
\end{tabular}

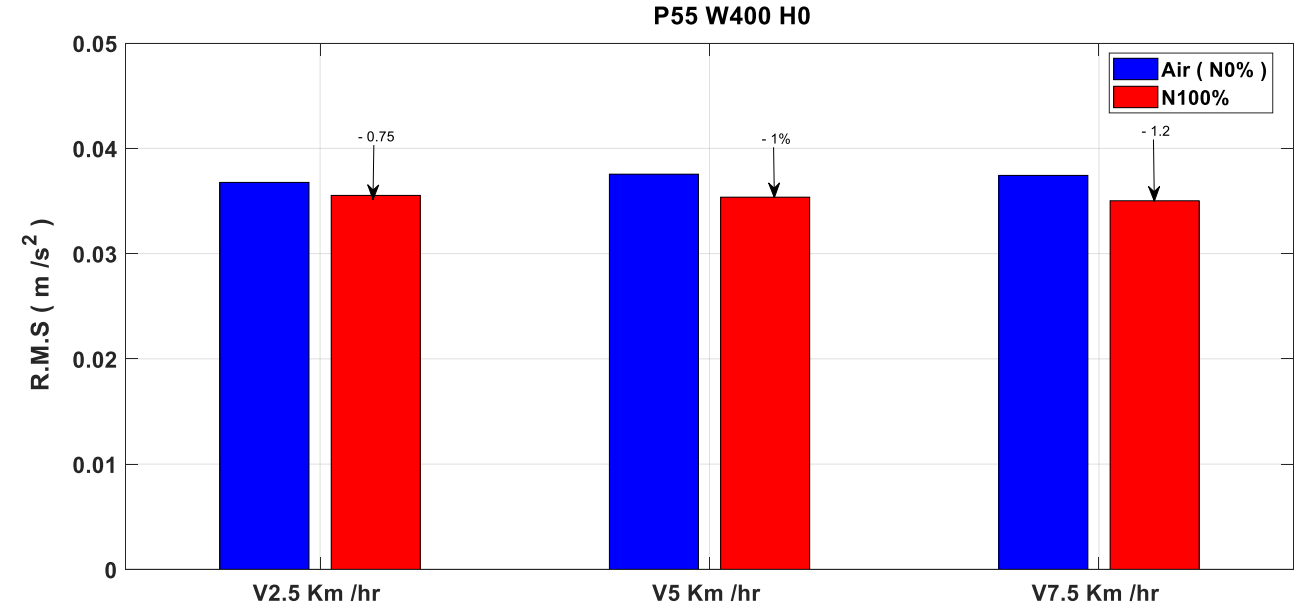

Figure -3. Summary of RMS versus different air, nitrogen without speed hump at Ms=400 kg, P55 Air (N0\%), nitrogen (N100\%) 


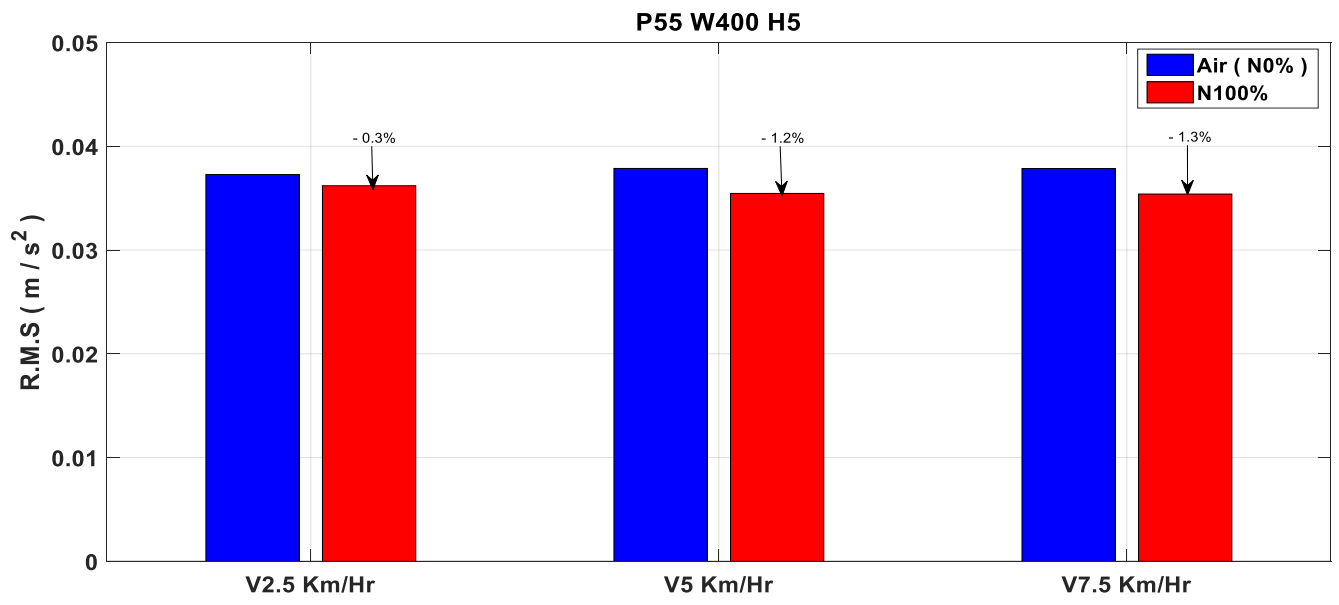

Figure - 4. Summary of RMS versus different air, nitrogen with speed hump at Ms=400 kg, P55psi Air (N0\%), nitrogen (N100\%)

Figure -2 shows the effect of tire speed on the ride comfort at sprung mass weight of $400 \mathrm{~kg}$. Without speed hump

(i.e. $\mathrm{h}=0$ ), when pressure 55psi, using air (nitrogen zero\% percentage) it can be seen that the RMS value of the body acceleration increase by $2.2 \%$ with the increase of tire speed from $2.5 \mathrm{~km} / \mathrm{hr}$ to $5 \mathrm{~km} / \mathrm{hr}$ and increase by $1.9 \%$ when it increases from $5 \mathrm{~km} / \mathrm{hr}$ to $7.5 \mathrm{~km} / \mathrm{hr}$. At speed humps height $50 \mathrm{~mm}$ it can be seen that the RMS value of the body acceleration increase by $1.6 \%$ with the increase of tire speed from $2.5 \mathrm{~km} / \mathrm{hr}$ to $5 \mathrm{~km} / \mathrm{hr}$ and increase by $1.53 \%$ when it increases from $5 \mathrm{~km} / \mathrm{hr}$ to $7.5 \mathrm{~km} / \mathrm{hr}$. The difference between the RMS values with and without speed hump at sprung mass weight $400 \mathrm{~kg}$ is $1.5 \%$ at $2.5 \mathrm{~km} / \mathrm{hr}, 1 \%$ at $5 \mathrm{~km} / \mathrm{hr}$ and $1.2 \%$ at $7.5 \mathrm{~km} / \mathrm{hr}$ respectively as shown in Table. 1

\section{Effect of tire speed on the vehicle vibration, pressure $55 p s i$ and $M s=480 \mathrm{~kg}$.}

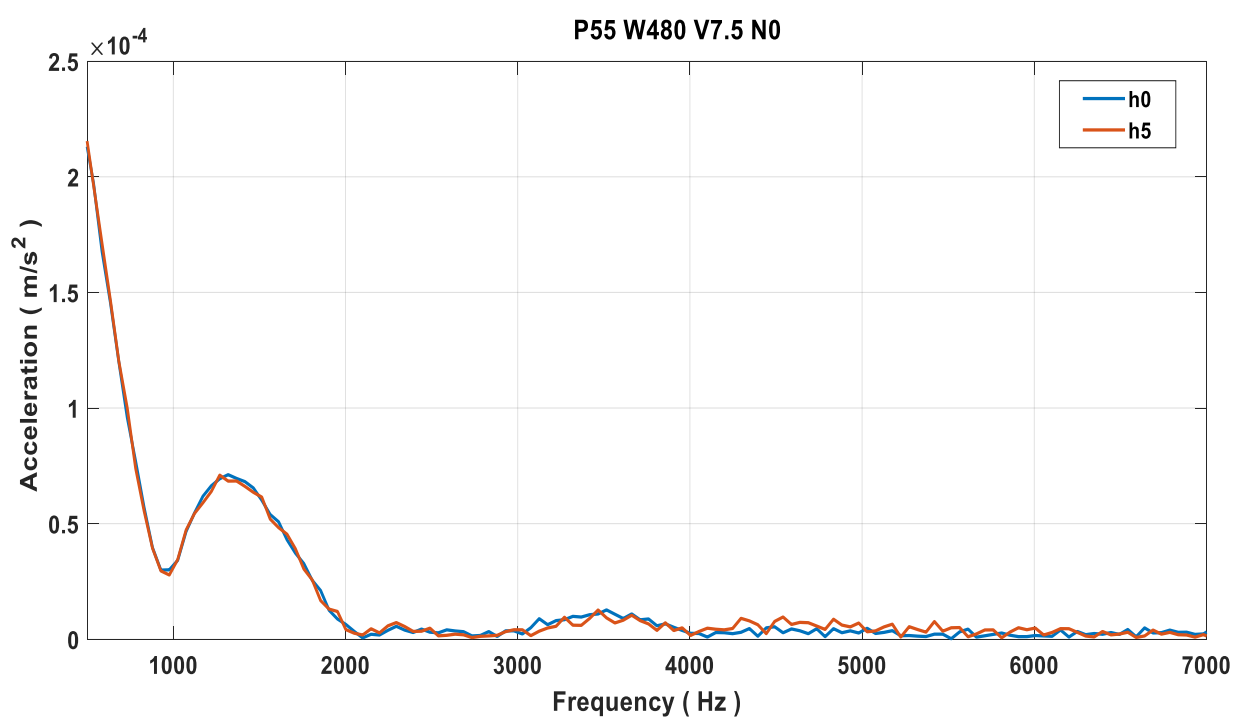

(a)Vehicle acceleration versus frequency without/ with speed hump at tire speed of $7.5 \mathrm{~km} / \mathrm{hr}$, pressure $55 \mathrm{psi}$ and $M s=480 \mathrm{~kg}$, nitrogen zero\% 
International Journal of Advances in Scientific Research and Engineering (ijasre), Vol 5 (5), May-2019

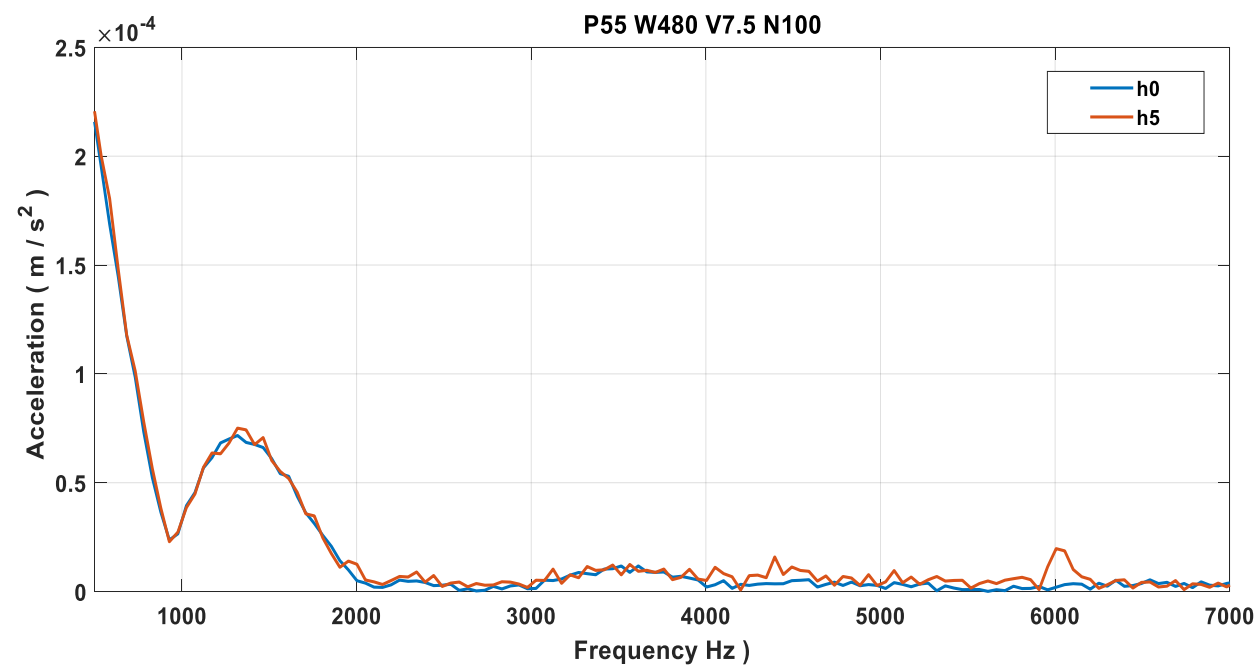

(b)Vehicle acceleration versus frequency without/with Speed hump at tire speed of $7.5 \mathrm{~km} / \mathrm{hr}$, pressure $55 \mathrm{psi}$ and $\mathrm{Ms}=480 \mathrm{~kg}$, nitrogen $100 \%$

Figure - 5. Vehicle acceleration versus frequency without/with speed hump, pressure $55 \mathrm{psi}$ and $\mathrm{Ms}=480 \mathrm{~kg}$, different tire speeds.at nitrogen zero \%, nitrogen $100 \%$.

Table-2. Experimental results of r.m.s for pressure 55psi, sprung mass weight of $480 \mathrm{~kg}$ and Air (N0\%), nitrogen (N100\%)

\begin{tabular}{|l|l|l|l|l|}
\hline \multirow{2}{*}{$\begin{array}{l}\text { Height speed hump }(\mathrm{mm}) \\
\text { Body vertical acceleration }\left(\mathrm{m} / \mathrm{s}^{2}\right)\end{array}$} & \multicolumn{2}{l}{ h0 (0) } & \multicolumn{2}{l|}{ h5 (50) } \\
\cline { 2 - 6 } & $\begin{array}{l}\text { Air } \\
(\mathrm{N} 0 \%)\end{array}$ & $\begin{array}{l}\text { Nitrogen } \\
(100 \%)\end{array}$ & $\begin{array}{l}\text { Air } \\
(\mathrm{N} 0 \%)\end{array}$ & $\begin{array}{l}\text { Nitrogen } \\
(100 \%)\end{array}$ \\
\hline Body vertical acceleration $\left(\mathrm{m} / \mathrm{s}^{2}\right)$ at V $2.5 \mathrm{~km} / \mathrm{hr}$ & 0.037540 & 0.036973 & 0.037789 & 0.037015 \\
\hline Body vertical acceleration $\left(\mathrm{m} / \mathrm{s}^{2}\right)$ at V $5 \mathrm{~km} / \mathrm{hr}$ & 0.037740 & 0.037181 & 0.037788 & 0.037500 \\
\hline Body vertical acceleration $\left(\mathrm{m} / \mathrm{s}^{2}\right)$ at V $7.5 \mathrm{~km} / \mathrm{hr}$ & 0.037150 & 0.036363 & 0.037324 & 0.036670 \\
\hline
\end{tabular}

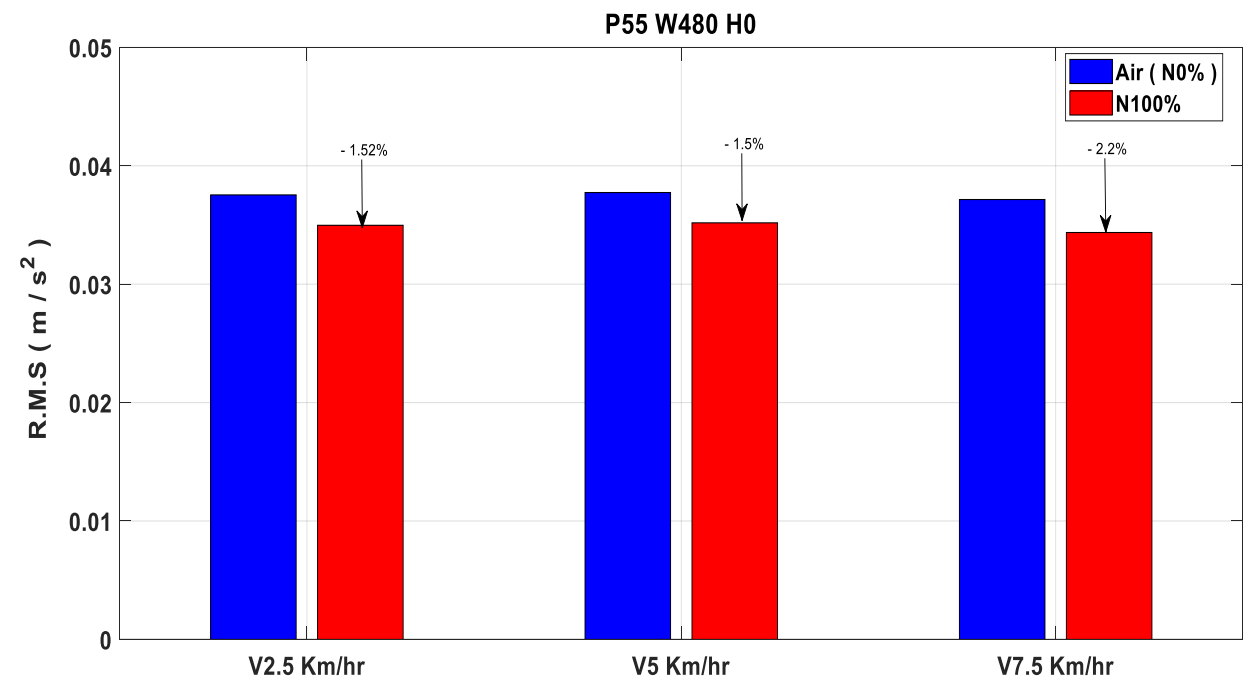

Figure -6. Summary of RMS versus different air, nitrogen without speed hump at Ms=480 $\mathrm{kg}$, pressure $55 \mathrm{psi}$ Air (N0\%), nitrogen (N100\%) 


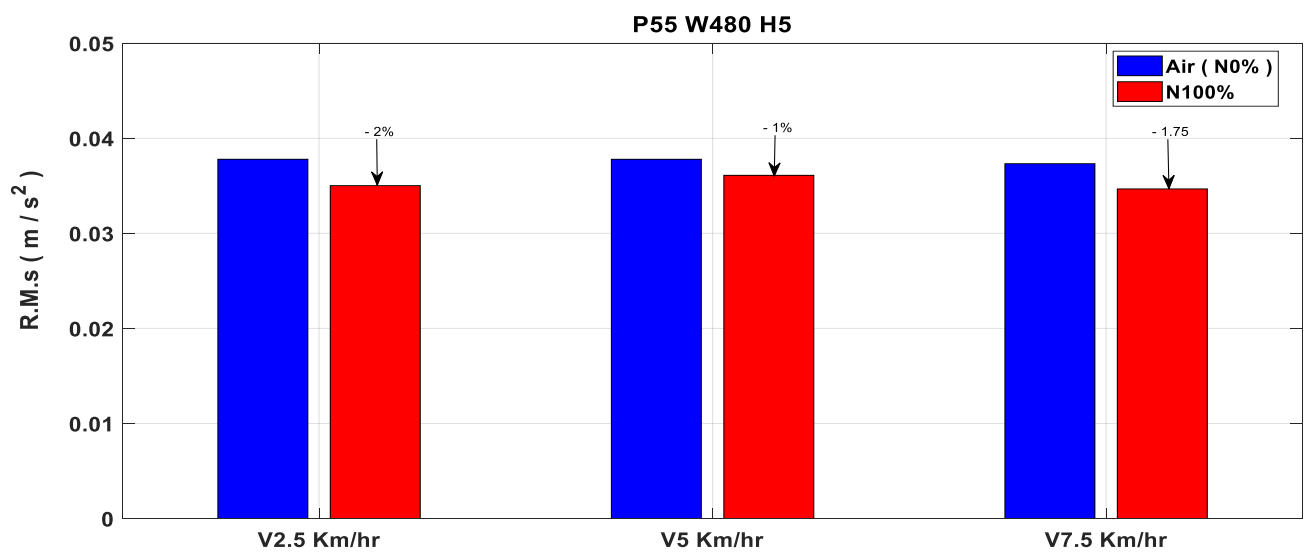

Figure - 7. Summary of RMS versus different air, nitrogen with speed hump at Ms=480 kg, pressure 55psi Air (N0\%), nitrogen (N100\%)

5. Pressure 55psi Air (N0\%), nitrogen (N100\%)

Figure - 5. shows the effect of tire speed on the ride comfort at sprung mass weight of $480 \mathrm{~kg}$. Without speed hump (i.e. $\mathrm{h}=0$ ), when pressure 55psi, using nitrogen $100 \%$ percentage, it can be seen that the RMS value of the body acceleration increase by $1.75 \%$ with the increase of tire speed from $2.5 \mathrm{~km} / \mathrm{hr}$ to $5 \mathrm{~km} / \mathrm{hr}$ and increase by $1.3 \%$ when it increases from $5 \mathrm{~km} / \mathrm{hr}$ to $7.5 \mathrm{~km} / \mathrm{hr}$. At speed humps height $50 \mathrm{~mm}$ it can be seen that the RMS value of the body acceleration increase by $0.7 \%$ with the increase of tire speed from $2.5 \mathrm{~km} / \mathrm{hr}$ to $5 \mathrm{~km} / \mathrm{hr}$ and increase by $0.5 \%$ when it increases from $5 \mathrm{~km} / \mathrm{hr}$ to $7.5 \mathrm{~km} / \mathrm{hr}$. The difference between the RMS values with and without speed hump at sprung mass weight 400 $\mathrm{kg}$ is $2 \%$ at $2.5 \mathrm{~km} / \mathrm{hr}, 0.8 \%$ at $5 \mathrm{~km} / \mathrm{hr}$ and $1 \%$ at $7.5 \mathrm{~km} / \mathrm{hr}$ respectively as shown in Table 2 .

Effect of the tire inflation pressure on vehicle vibration, on the ride comfort

\section{Pressure 50 psi, sprung mass weight of $400 \mathrm{~kg}, \mathrm{~h}=0$}

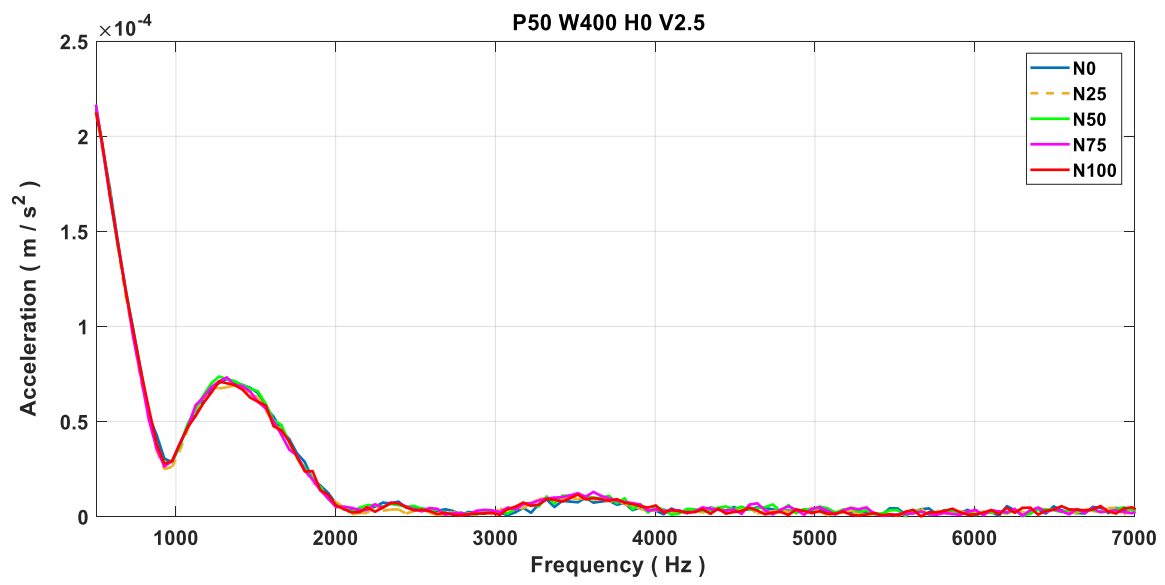

Figure -8. Vehicle acceleration versus frequency without speed hump at tire speed of $2.5 \mathrm{~km} / \mathrm{hr}$, pressure $50 \mathrm{psi}$ and $M s=400 \mathrm{~kg}$ and different ratios of nitrogen.

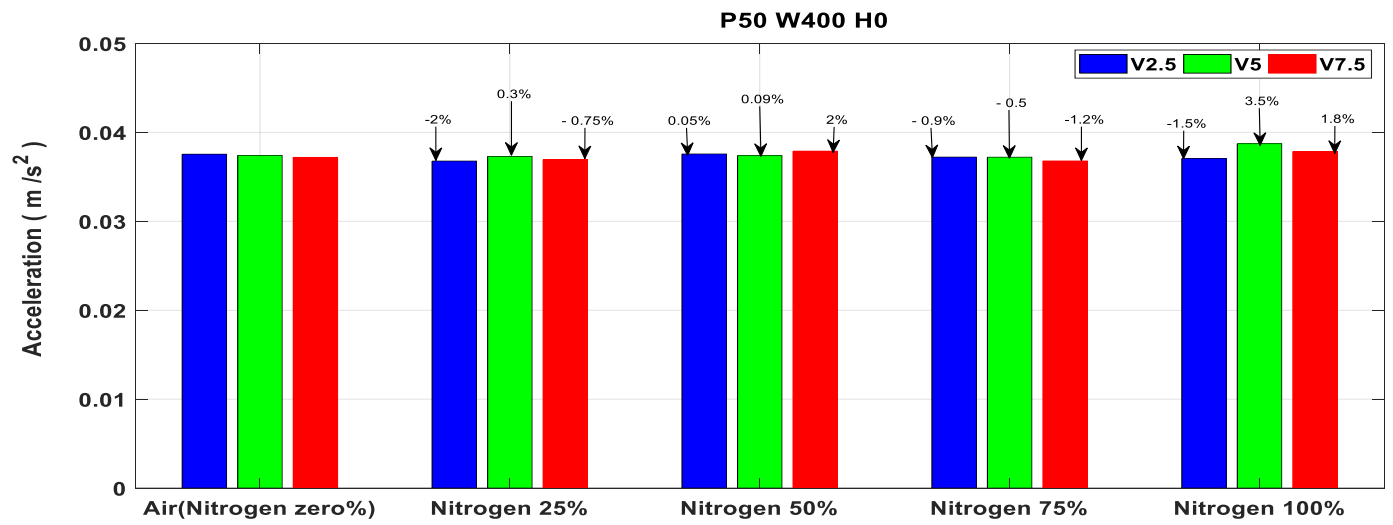

Figure- 9. Summary of RMS versus different ratios of nitrogen with speed hump at Ms=400 $\mathrm{kg}$, pressure 50 psi 
International Journal of Advances in Scientific Research and Engineering (ijasre), Vol 5 (5), May-2019

Table -3. Experimental results of r.m.s values at different tire speed for sprung mass weight of $400 \mathrm{~kg}$, pressure 50 psi, without speed hump (i.e. $\mathrm{h}=0$ ) and different ratios of nitrogen

\begin{tabular}{|l|l|l|l|}
\hline \multicolumn{1}{|c|}{$\begin{array}{l}\text { Body vertical acceleration } \\
\left(\mathrm{m} / \mathrm{s}^{2}\right)\end{array}$} & $\begin{array}{l}\text { Body vertical } \\
\text { acceleration } \\
\left(\mathrm{m} / \mathrm{s}^{2}\right) \\
\text { at V } 2.5 \mathrm{~km} / \mathrm{hr}\end{array}$ & $\begin{array}{l}\text { Body vertical } \\
\text { acceleration } \\
\left(\mathrm{m} / \mathrm{s}^{2}\right) \\
\text { at V5 } \mathrm{km} / \mathrm{hr}\end{array}$ & $\begin{array}{l}\text { Body vertical } \\
\text { acceleration } \\
\left(\mathrm{m} / \mathrm{s}^{2}\right) \\
\text { at V } 7.5 \mathrm{~km} / \mathrm{hr}\end{array}$ \\
\hline Air ( Nitrogen zero\%) & 0.037556 & 0.037409 & 0.037203 \\
\hline Nitrogen $25 \%$ & 0.036783 & 0.037307 & 0.036930 \\
\hline Nitrogen $50 \%$ & 0.037577 & 0.037376 & 0.037903 \\
\hline Nitrogen $75 \%$ & 0.037229 & 0.037217 & 0.036796 \\
\hline Nitrogen $100 \%$ & 0.037074 & 0.038720 & 0.037861 \\
\hline
\end{tabular}

Figure -8. shows the effect of the tire inflation pressure on the ride comfort at tire speed of $2.5 \mathrm{~km} / \mathrm{hr}$ and sprung mass weight of $400 \mathrm{~kg}$. pressure 50 psi Without speed hump (i.e. $\mathrm{h}=0$ ), it can be seen that the RMS value of the body acceleration is decrease $\mathrm{s}$ When used Nitrogen $25 \%-2 \%$ when the tire inflation is changed from Nitrogen $50 \%$, the body acceleration is increased by 0.05 $\%$ when the tire inflation is changed from Nitrogen $75 \%$, the body acceleration is decreased by $-0.9 \%$ when the tire inflation is changed from Nitrogen $100 \%$ the body acceleration is decreased by $-1.5 \%$ at tire speed of $5 \mathrm{~km} / \mathrm{hr}$ and sprung mass weight of $400 \mathrm{~kg}$. pressure 50 psi Without speed hump (i.e. $\mathrm{h}=0$ ), it can be seen that the RMS value of the body acceleration is decreases When used Nitrogen $25 \%-0.3 \%$ when the tire inflation is changed from Nitrogen $50 \%$, the body acceleration is increased by $0.09 \%$ when the tire inflation is changed from Nitrogen $75 \%$, the body acceleration is decreased by $-0.5 \%$ when the tire inflation is changed from Nitrogen $100 \%$ the body acceleration is increased by $3.5 \%$ at tire speed of $7.5 \mathrm{~km} / \mathrm{hr}$ and sprung mass weight of $400 \mathrm{~kg}$. pressure 50 psi Without speed hump (i.e. $\mathrm{h}=0$ ), it can be seen that the RMS value of the body acceleration is decreases When used Nitrogen $25 \%-0.75 \%$ when the tire inflation is changed from Nitrogen $50 \%$, the body acceleration is increases by $2 \%$ when the tire inflation is changed from Nitrogen $75 \%$, the body acceleration is decreased by $-1.2 \%$ when the tire inflation is changed from Nitrogen $100 \%$ the body acceleration is increased by $1.8 \%$

\section{Pressure 50 psi, sprung mass weight of $400 \mathrm{~kg}$, h5}

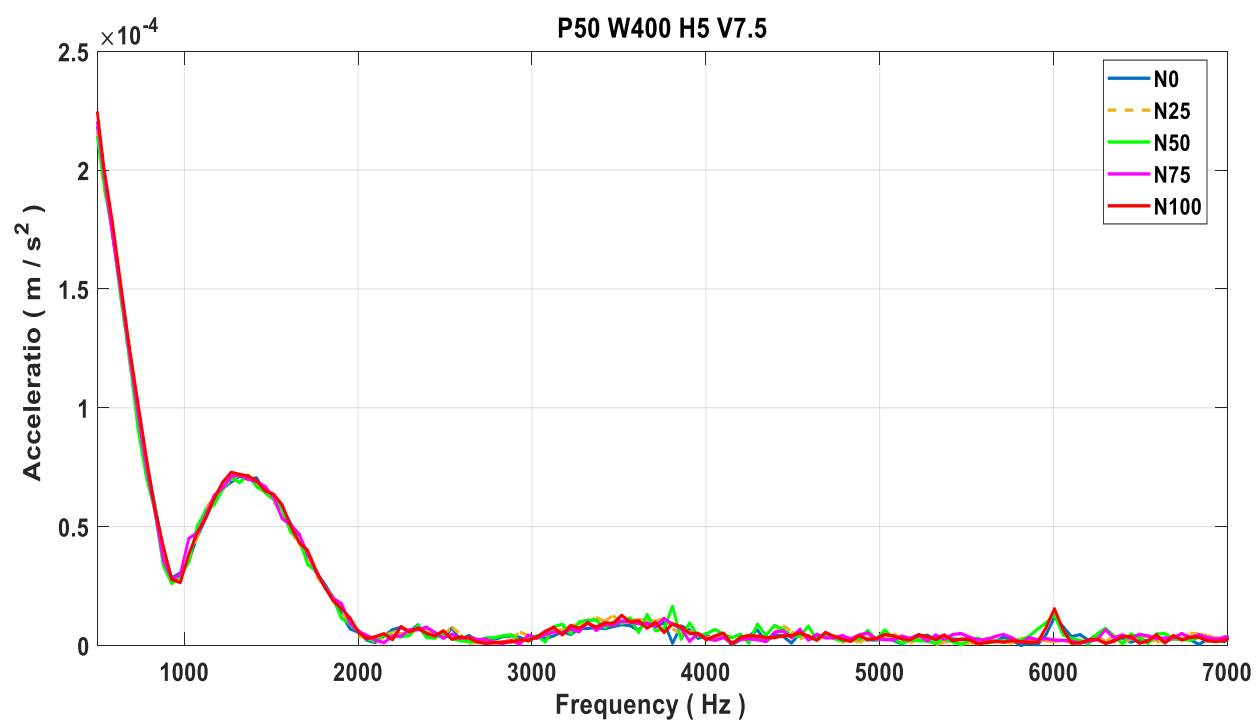

Figure -10. Vehicle acceleration versus frequency with speed hump at tire speed of $2.5 \mathrm{~km} / \mathrm{hr}$, pressure $50 \mathrm{psi}$ and $\mathrm{Ms}=400 \mathrm{~kg}$ and different ratios of nitrogen 


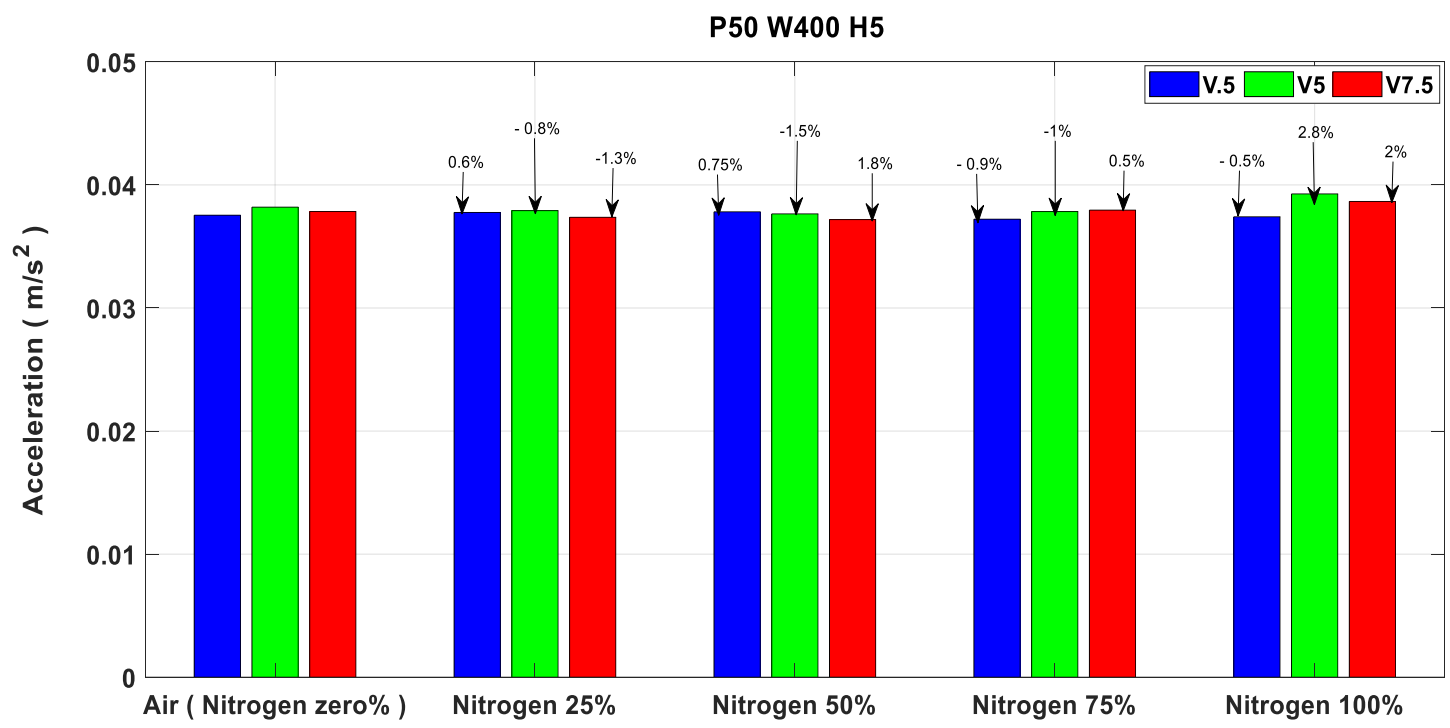

Figure -11. Summary of RMS versus different ratios of nitrogen with speed hump at Ms=400 kg, pressure 50 psi

Table - 4. Experimental results of r.m.s values at different tire speed for sprung mass weight of $400 \mathrm{~kg}$, pressure 50psi, with speed hump (i.e. $\mathrm{h}=50$ ) and different ratios of nitrogen

\begin{tabular}{|l|l|l|l|}
\hline $\begin{array}{c}\text { Bedy vertical acceleration } \\
\left(\mathrm{m} / \mathrm{s}^{2}\right)\end{array}$ & $\begin{array}{l}\text { Body vertical } \\
\text { acceleration }\left(\mathrm{m} / \mathrm{s}^{2}\right) \\
\text { at V 2.5 km/hr }\end{array}$ & $\begin{array}{l}\text { Body vertical } \\
\text { acceleration }(\mathrm{m} / \mathrm{s} 2) \\
\text { at V5 } \mathrm{km} / \mathrm{hr}\end{array}$ & $\begin{array}{l}\text { Body vertical } \\
\text { acceleration }\left(\mathrm{m} / \mathrm{s}^{2}\right) \\
\text { at V 7.5 km/hr }\end{array}$ \\
\hline Air ( Nitrogen zero\%) & 0.037542 & 0.038196 & 0.037833 \\
\hline Nitrogen 25\% & 0.037766 & 0.037908 & 0.037372 \\
\hline Nitrogen 50\% & 0.037816 & 0.037647 & 0.037179 \\
\hline Nitrogen 75\% & 0.037217 & 0.037831 & 0.037954 \\
\hline Nitrogen 100\% & 0.037411 & 0.039270 & 0.038660 \\
\hline
\end{tabular}

Figure -10. shows the effect of the tire inflation pressure on the ride comfort at tire speed of $2.5 \mathrm{~km} / \mathrm{hr}$ and sprung mass weight of $400 \mathrm{~kg}$. Pressure 50 psi with speed hump (i.e. $\mathrm{h}=50$ ), it can be seen that the RMS value of the body acceleration is increased When used Nitrogen 25\%. $0.6 \%$ when the tire inflation is changed from Nitrogen 50\%, the body acceleration is increased by $0.75 \%$ when the tire inflation is changed from Nitrogen $75 \%$, the body acceleration is decreased by -0.9 $\%$ when the tire inflation is changed from Nitrogen $100 \%$ the body acceleration is decreased by $-0.5 \%$.at tire speed of $5 \mathrm{~km} / \mathrm{hr}$ and sprung mass weight of $400 \mathrm{~kg}$. pressure $50 \mathrm{psi}$ Without speed hump (i.e. $\mathrm{h}=50$ ), it can be seen that the RMS value of the body acceleration is decreases When used Nitrogen $25 \%-0.8 \%$ when the tire inflation is changed from Nitrogen $50 \%$, the body acceleration is decreases by $-1.5 \%$ when the tire inflation is changed from Nitrogen $75 \%$, the body acceleration is decreased by $-1 \%$ when the tire inflation is changed from Nitrogen $100 \%$ the body acceleration is increased by $2.8 \%$ at tire speed of $7.5 \mathrm{~km} / \mathrm{hr}$ and sprung mass weight of $400 \mathrm{~kg}$. pressure 50 psi Without speed hump (i.e. h=50), it can be seen that the RMS value of the body acceleration is decreases When used Nitrogen $25 \%-1.3 \%$ when the tire inflation is changed from Nitrogen $50 \%$, the body acceleration is increases by $1.8 \%$ when the tire inflation is changed from Nitrogen $75 \%$, the body acceleration is increased by $0.5 \%$ when the tire inflation is changed from Nitrogen $100 \%$ the body acceleration is increased by $2 \%$. 


\section{Pressure 55 psi, sprung mass weight of $400 \mathrm{~kg}$, h0}

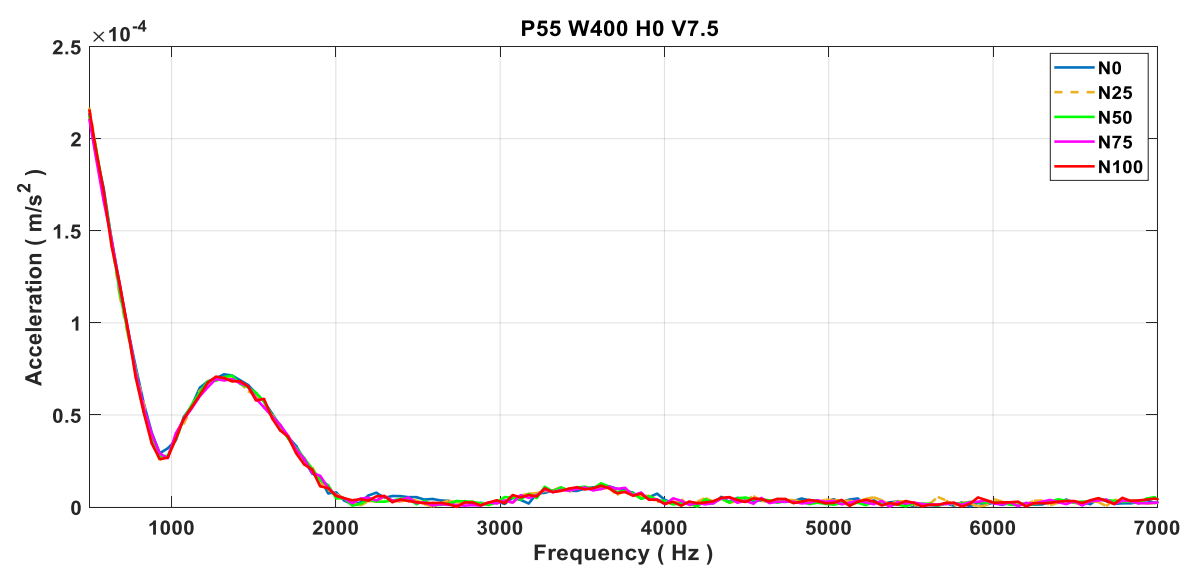

Figure -12 . Vehicle acceleration versus frequency without speed hump at tire speed of $7.5 \mathrm{~km} / \mathrm{hr}$, pressure $55 \mathrm{psi}$ and $\mathrm{MS}=$ $400 \mathrm{~kg}$ and different ratios of nitrogen.

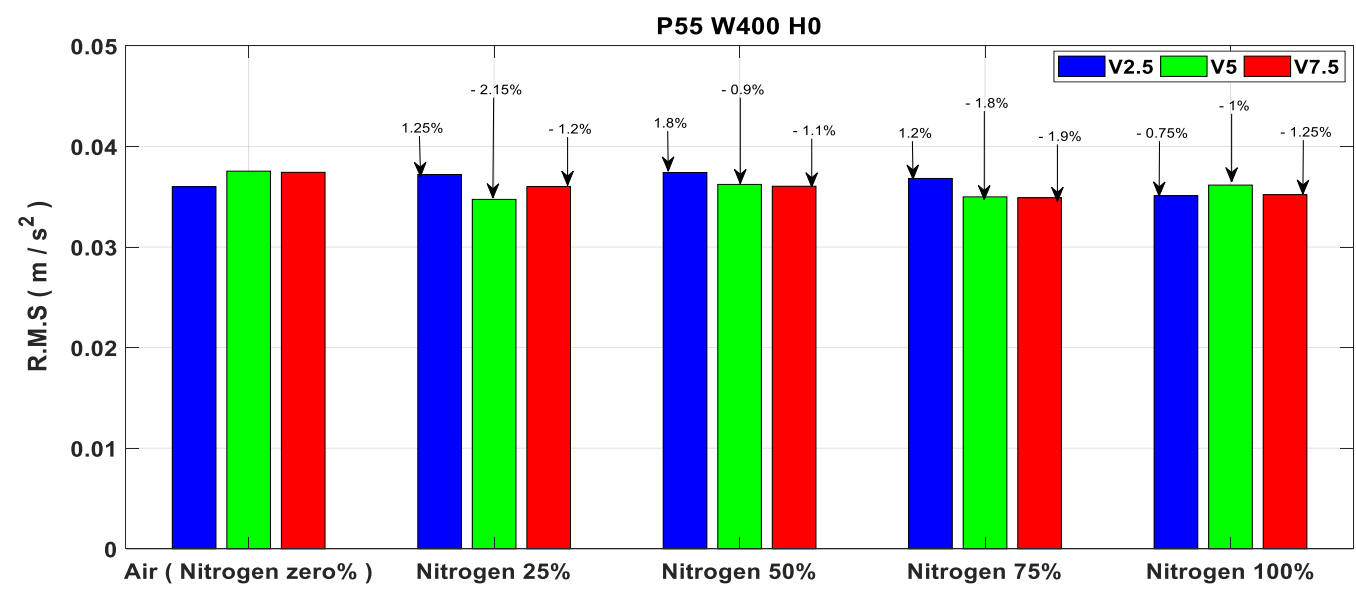

Figure -13. Summary of RMS versus different ratios of nitrogen, without speed hump at MS=400 kg, pressure 55psi

Table -5. Experimental results of r.m.s values at different tire speed for sprung mass weight of $400 \mathrm{~kg}$, pressure $55 \mathrm{psi}$ without speed hump (i.e. $\mathrm{h}=0$ ) and different ratios of nitrogen

\begin{tabular}{|c|c|c|c|}
\hline filling tire (air, nitrogen) & $\begin{array}{l}\text { Body vertical } \\
\text { acceleration }\left(\mathrm{m} / \mathrm{s}^{2}\right) \\
\text { at V } 2.5 \mathrm{~km} / \mathrm{hr}\end{array}$ & 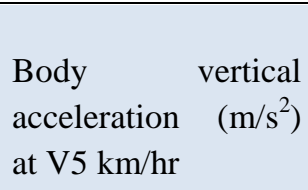 & $\begin{array}{l}\text { Body vertical } \\
\text { acceleration }\left(\mathrm{m} / \mathrm{s}^{2}\right) \\
\text { at V } 7.5 \mathrm{~km} / \mathrm{hr}\end{array}$ \\
\hline Air ( Nitrogen zero\%) & 0.036765 & 0.037546 & 0.037430 \\
\hline Nitrogen $25 \%$ & 0.037216 & 0.036739 & 0.037013 \\
\hline Nitrogen $50 \%$ & 0.037415 & 0.037227 & 0.037047 \\
\hline Nitrogen $75 \%$ & 0.037184 & 0.036899 & 0.036723 \\
\hline Nitrogen $100 \%$ & 0.036530 & 0.037162 & 0.037000 \\
\hline
\end{tabular}

Figure -12. shows the effect of the tire inflation pressure on the ride comfort at tire speed of $2.5 \mathrm{~km} / \mathrm{hr}$ and sprung mass weight of $400 \mathrm{~kg}$. pressure 55 psi without speed hump (i.e. $\mathrm{h}=0$ ), it can be seen that the RMS value of the body acceleration is increased When used Nitrogen 25\% $1.25 \%$ when the tire inflation is changed from Nitrogen $50 \%$, the body acceleration is increased by $1.8 \%$ when the tire inflation is changed from Nitrogen $75 \%$, the body acceleration is increased by $1.2 \%$ when the tire inflation is changed from Nitrogen $100 \%$ the body acceleration is decreased by $-0.75 \%$ at tire speed of $5 \mathrm{~km} / \mathrm{hr}$ and sprung mass weight of $400 \mathrm{~kg}$. . pressure 55 psi without speed hump (i.e. $\mathrm{h}=0$ ), it can be seen that the RMS value of the body acceleration is decreases when used Nitrogen $25 \%-2.15 \%$ when the tire inflation is changed from Nitrogen $50 \%$, the body 
acceleration is decreases by $-0.9 \%$ when the tire inflation is changed from Nitrogen $75 \%$, the body acceleration is decreased by $-1.8 \%$ when the tire inflation is changed from Nitrogen $100 \%$ the body acceleration is decreases by $-1 \%$ At tire speed of 7.5 $\mathrm{km} / \mathrm{hr}$ and sprung mass weight of $400 \mathrm{~kg}$. pressure 55 psi without speed hump (i.e. $\mathrm{h}=0$ ), it can be seen that the RMS value of the body acceleration is decreases when used Nitrogen $25 \%-1.2 \%$ when the tire inflation is changed from Nitrogen $50 \%$, the body acceleration is decreases by $-1.1 \%$ when the tire inflation is changed from Nitrogen $75 \%$, the body acceleration is decreased by $-1.9 \%$ when the tire inflation is changed from Nitrogen $100 \%$ the body acceleration is decreases by $-1.25 \%$

\section{Pressure 55 psi, sprung mass weight of $400 \mathrm{~kg}$, h5}

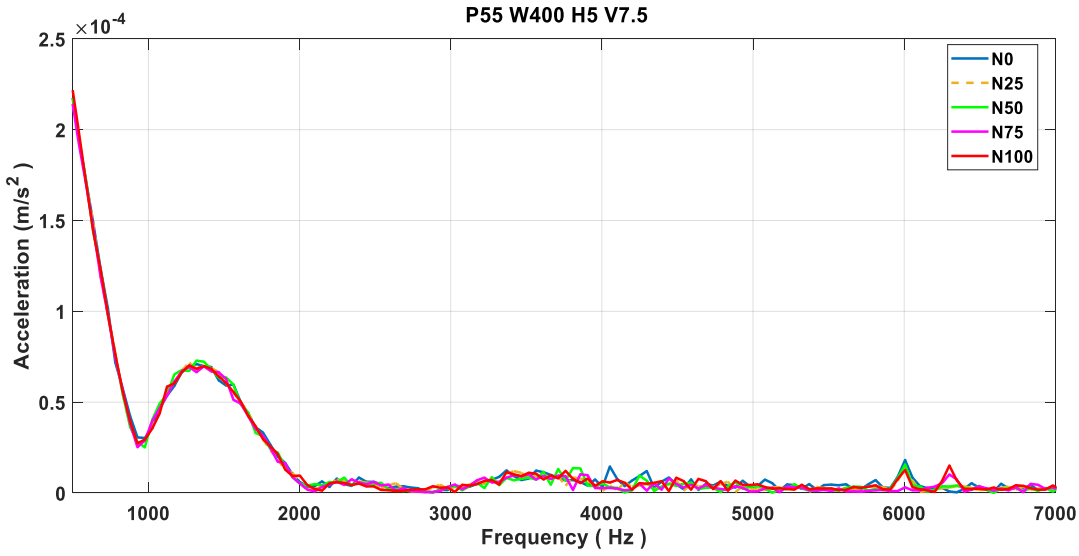

Figure -14 . Vehicle acceleration versus frequency with speed hump at tire speed of $7.5 \mathrm{~km} / \mathrm{hr}$, pressure $55 \mathrm{psi}$ and MS=400 $\mathrm{kg}$ and different ratios of nitrogen.

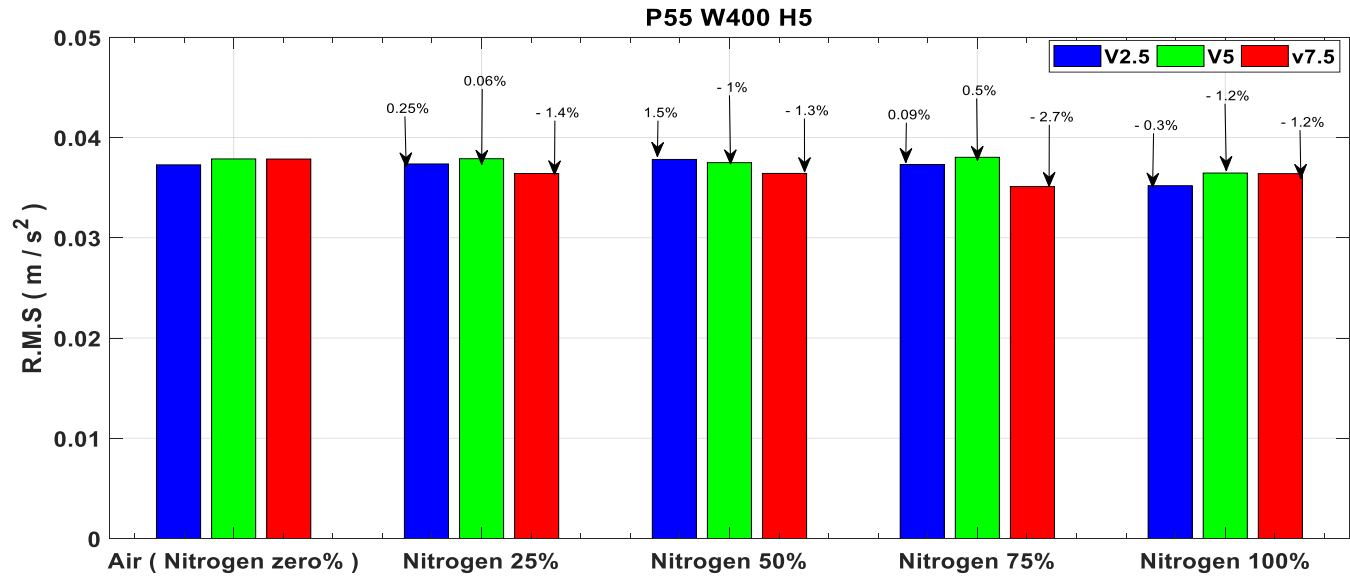

Figure - 15. Summary of RMS versus different ratios of nitrogen, with speed hump at Ms=400 $\mathrm{kg}$, pressure $55 \mathrm{psi}$

Table -6. Experimental results of r.m.s values at different tire speed for sprung mass weight of $400 \mathrm{~kg}$, pressure $55 \mathrm{psi}$, with speed hump (i.e. $\mathrm{h}=50$ ) and different ratios of nitrogen.

\begin{tabular}{|l|l|l|l|}
\hline $\begin{array}{c}\text { Body vertical acceleration } \\
\left(\mathrm{m} / \mathrm{s}^{2}\right)\end{array}$ & $\begin{array}{l}\text { Body vertical } \\
\text { acceleration }\left(\mathrm{m} / \mathrm{s}^{2}\right) \\
\text { filling tire (air, nitrogen) }\end{array}$ & $\begin{array}{l}\text { Body vertical } \\
\text { acceleration }\left(\mathrm{m} / \mathrm{s}^{2}\right) \\
\mathrm{V} 5 \mathrm{~km} / \mathrm{hr}\end{array}$ & $\begin{array}{l}\text { Body } \\
\text { acceleration }\left(\mathrm{m} / \mathrm{s}^{2}\right) \text { at } \\
\mathrm{V} 7.5 \mathrm{~km} / \mathrm{hr}\end{array}$ \\
\hline Air ( Nitrogen zero\%) & 0.037279 & 0.037866 & 0.037850 \\
\hline Nitrogen 25\% & 0.037367 & 0.037888 & 0.037352 \\
\hline Nitrogen 50\% & 0.037816 & 0.037495 & 0.037590 \\
\hline Nitrogen 75\% & 0.037309 & 0.038028 & 0.037034 \\
\hline Nitrogen $100 \%$ & 0.037200 & 0.037458 & 0.037400 \\
\hline
\end{tabular}


Figure- 14. shows the effect of the tire inflation pressure on the ride comfort at tire speed of $2.5 \mathrm{~km} / \mathrm{hr}$ and sprung mass weight of $400 \mathrm{~kg}$. pressure 55 psi with speed hump (i.e. $\mathrm{h}=50$ ), it can be seen that the RMS value of the body acceleration is increased When used Nitrogen $25 \% \quad 0.25 \%$ when the tire inflation is changed from Nitrogen $50 \%$, the body acceleration is increased by $1.5 \%$ when the tire inflation is changed from Nitrogen $75 \%$, the body acceleration is increased by $0.09 \%$ when the tire inflation is changed from nitrogen $100 \%$ the body acceleration is decreased by $-0.22 \%$ at tire speed of $5 \mathrm{~km} / \mathrm{hr}$ and sprung mass weight of 400 $\mathrm{kg}$. . pressure 55 psi with speed hump (i.e. $\mathrm{h}=50$ ), it can be seen that the RMS value of the body acceleration is increased when used Nitrogen $25 \% 0.06 \%$ when the tire inflation is changed from Nitrogen $50 \%$, the body acceleration is decreases by - $1 \%$ when the tire inflation is changed from Nitrogen $75 \%$, the body acceleration is increased by $0.5 \%$ when the tire inflation is changed from Nitrogen $100 \%$ the body acceleration is decreases by $-1.2 \%$ at tire speed of $7.5 \mathrm{~km} / \mathrm{hr}$ and sprung mass weight of 400 $\mathrm{kg}$. pressure 55 psi with speed hump (i.e. $\mathrm{h}=50$ ), it can be seen that the RMS value of the body acceleration is decreases when used Nitrogen $25 \%-1.4 \%$ when the tire inflation is changed from Nitrogen $50 \%$, the body acceleration is decreases by - 1.3 $\%$ when the tire inflation is changed from Nitrogen $75 \%$, the body acceleration is decreased by $-2.7 \%$ when the tire inflation is changed from Nitrogen $100 \%$ the body acceleration is decreases by $-1.2 \%$.

\section{Pressure 55 psi, sprung mass weight of $480 \mathrm{~kg}$, h0}

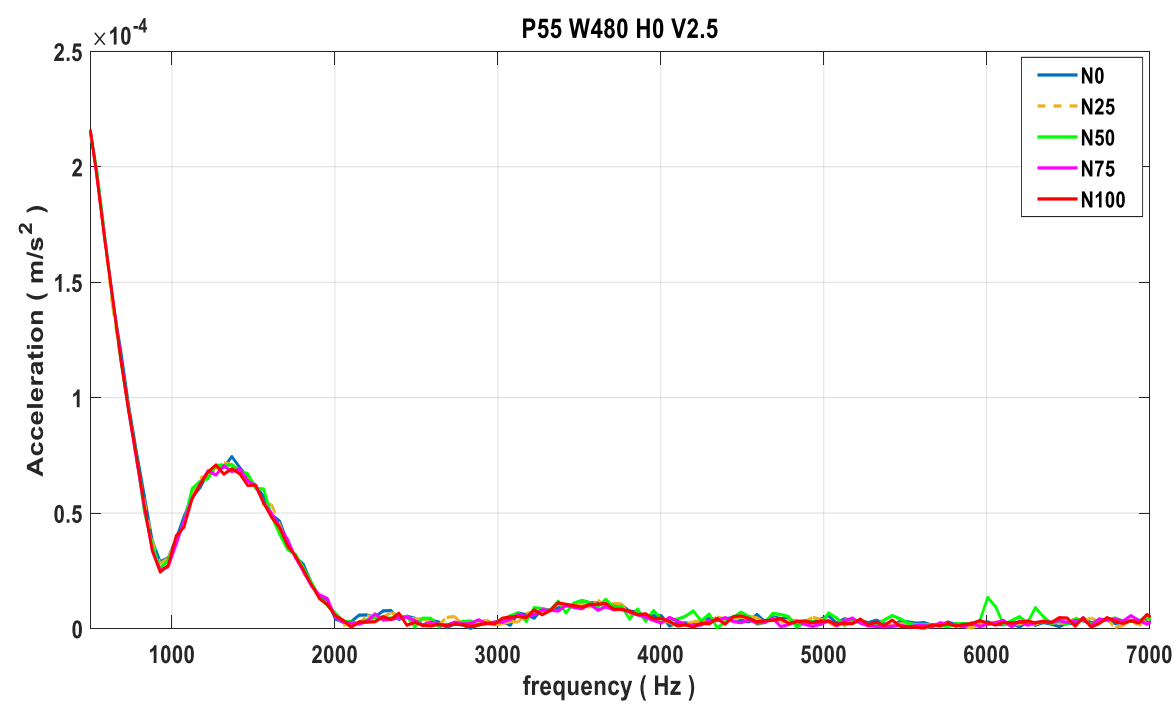

Figure -16 . Vehicle acceleration versus frequency without speed hump at tire speed of $2.5 \mathrm{~km} / \mathrm{hr}$, pressure $55 \mathrm{psi}$ and $\mathrm{Ms}=480$ $\mathrm{kg}$, and different ratio of nitrogen.

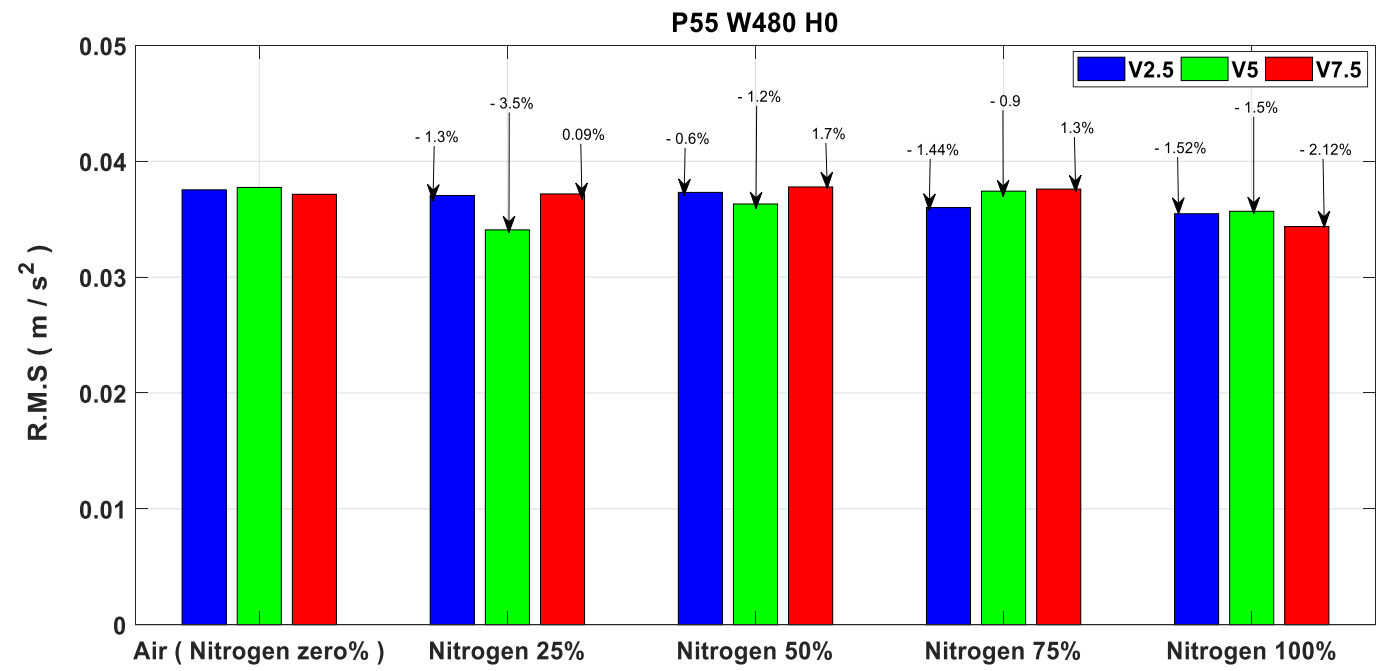

Figure - 17. Summary of RMS versus different ratios of nitrogen, without speed hump at $\mathrm{Ms}=480 \mathrm{~kg}$, pressure 55psi. 
Table -7. Experimental results of r.m.s values at different tire speed for sprung mass weight of $480 \mathrm{~kg}$, pressure 55psi, with speed hump (i.e. $\mathrm{h}=0$ ).

\begin{tabular}{|c|c|c|c|}
\hline filling tire (air, nitrogen) & $\begin{array}{l}\text { Body vertical } \\
\text { acceleration }\left(\mathrm{m} / \mathrm{s}^{2}\right) \\
\text { at V } 2.5 \mathrm{~km} / \mathrm{hr}\end{array}$ & $\begin{array}{ll}\text { Body } & \text { vertical } \\
\text { acceleration } & \left(\mathrm{m} / \mathrm{s}^{2}\right) \\
\text { V5 } \mathrm{km} / \mathrm{hr} & \text { at }\end{array}$ & $\begin{array}{l}\text { Body vertical } \\
\text { acceleration }\left(\mathrm{m} / \mathrm{s}^{2}\right) \text { at } \mathrm{V} \\
7.5 \mathrm{~km} / \mathrm{hr}\end{array}$ \\
\hline Air ( Nitrogen zero\% ) & 0.037540 & 0.037740 & 0.037150 \\
\hline Nitrogen 25\% & 0.037049 & 0.036429 & 0.037181 \\
\hline Nitrogen $50 \%$ & 0.037314 & 0.037312 & 0.037784 \\
\hline Nitrogen $75 \%$ & 0.037002 & 0.037422 & 0.037629 \\
\hline Nitrogen $100 \%$ & 0.036973 & 0.037181 & 0.036363 \\
\hline
\end{tabular}

Figure - 16. shows the effect of the tire inflation pressure on the ride comfort at tire speed of $2.5 \mathrm{~km} / \mathrm{hr}$ and sprung mass weight of $480 \mathrm{~kg}$. pressure $55 \mathrm{psi}$ without speed hump (i.e. $\mathrm{h}=0$ ), it can be seen that the RMS value of the body acceleration is decreased when used Nitrogen 25\% - $1.3 \%$ when the tire inflation is changed from Nitrogen $50 \%$, the body acceleration is decreased by $0.6 \%$ when the tire inflation is changed from Nitrogen $75 \%$, the body acceleration is decreased by $-1.44 \%$ when the tire inflation is changed from Nitrogen $100 \%$ the body acceleration is decreased by $-1.52 \%$ at tire speed of $5 \mathrm{~km} / \mathrm{hr}$ and sprung mass weight of 480 $\mathrm{kg}$. . pressure 55 psi without speed hump (i.e. $\mathrm{h}=0$ ), it can be seen that the RMS value of the body acceleration is decreased when used Nitrogen $25 \%-3.5 \%$ when the tire inflation is changed from Nitrogen $50 \%$, the body acceleration is decreases by $-1.2 \%$ when the tire inflation is changed from Nitrogen $75 \%$, the body acceleration is decreased by $-0.85 \%$ when the tire inflation is changed from Nitrogen $100 \%$ the body acceleration is decreases by $-1.5 \%$ at tire speed of $7.5 \mathrm{~km} / \mathrm{hr}$ and sprung mass weight of $480 \mathrm{~kg}$. pressure 55 psi without speed hump (i.e. $\mathrm{h}=0$ ), it can be seen that the RMS value of the body acceleration is increased when used Nitrogen 25\% $0.09 \%$ when the tire inflation is changed from Nitrogen 50\%, the body acceleration is increased by $1.7 \%$ when the tire inflation is changed from Nitrogen $75 \%$, the body acceleration is increased by $1.3 \%$ when the tire inflation is changed from Nitrogen $100 \%$ the body acceleration is decreases by $-2.12 \%$

\section{Pressure 55 psi, sprung mass weight of $480 \mathrm{~kg}$, h5}

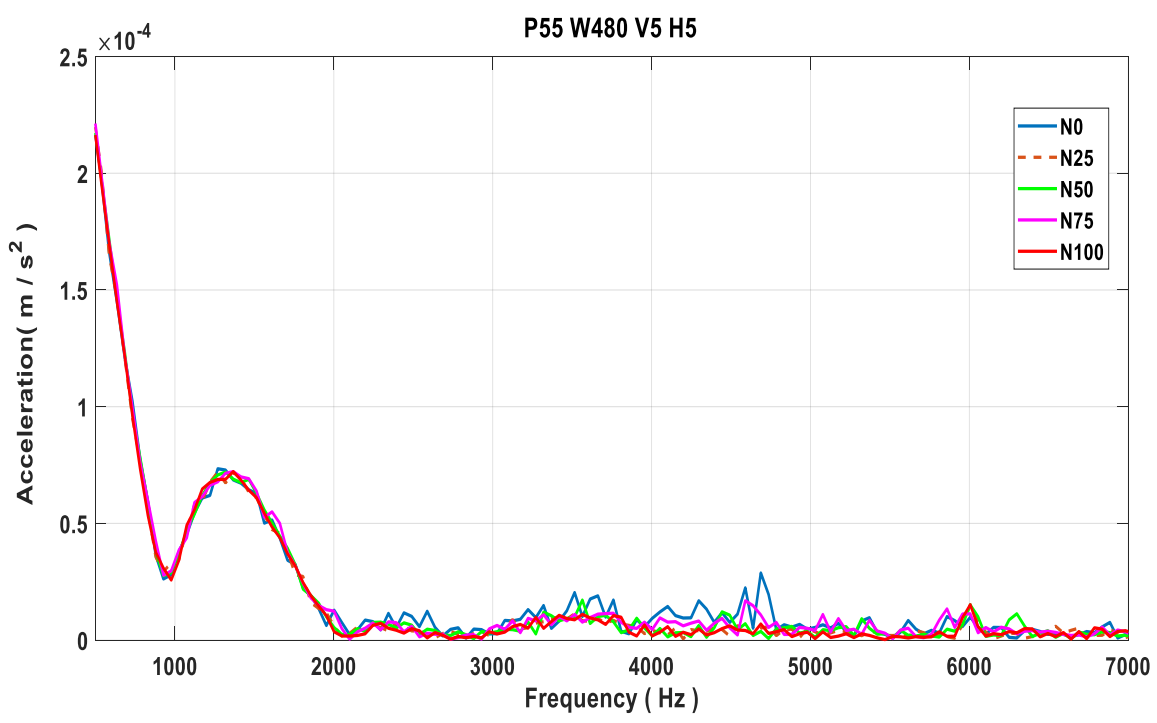

Figure -18 . Vehicle acceleration versus frequency with speed hump at tire speed of $5 \mathrm{~km} / \mathrm{hr}$, pressure $55 \mathrm{psi}$ and $\mathrm{Ms}=480 \mathrm{~kg}$ and different ratios of nitrogen. 


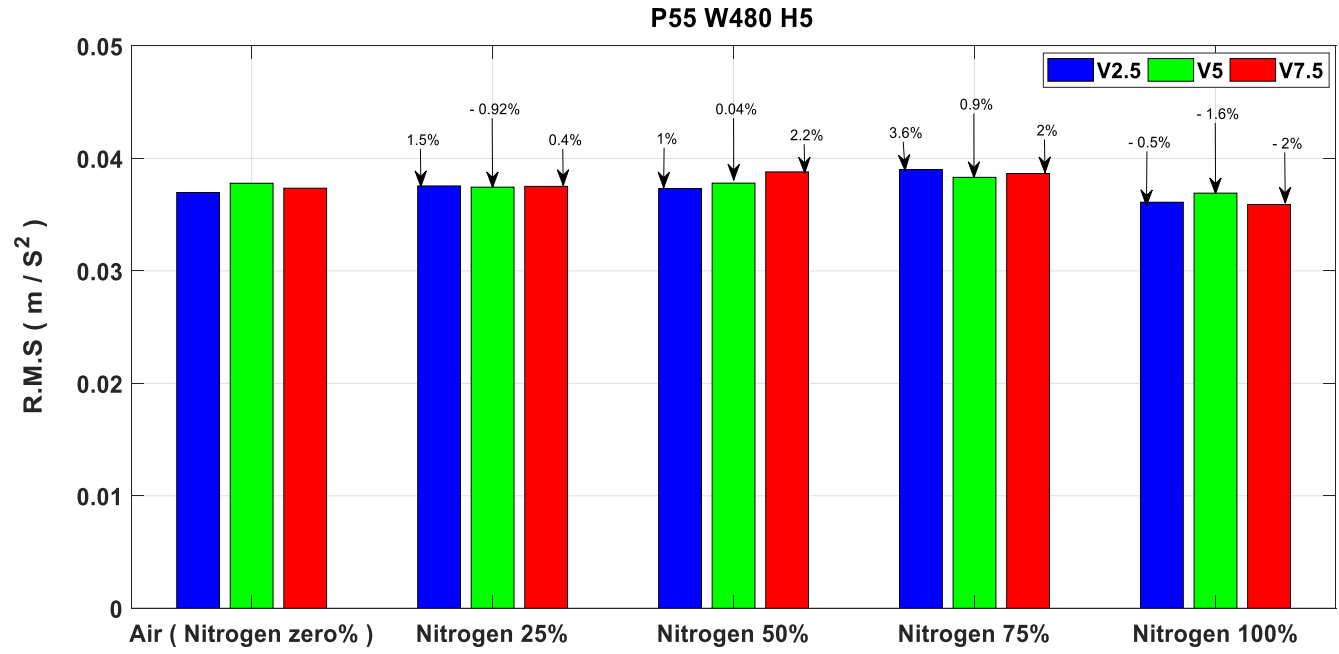

Figure - 19. Summary of RMS versus different ratios of nitrogen, with speed hump at Ms=480 $\mathrm{kg}$, pressure $55 \mathrm{psi}$ Table - 8. Experimental results of r.m.s values at different tire speed for sprung mass weight of $480 \mathrm{~kg}$, pressure $55 \mathrm{psi}$, with speed hump (i.e. $\mathrm{h}=50$ ) and different ratios of nitrogen.

\begin{tabular}{|c|c|c|c|}
\hline filling tire (air, nitrogen) & $\begin{array}{l}\text { Body vertical } \\
\text { acceleration }\left(\mathrm{m} / \mathrm{s}^{2}\right) \\
\text { at V } 2.5 \mathrm{~km} / \mathrm{hr}\end{array}$ & $\begin{array}{l}\text { Body vertical } \\
\text { acceleration }\left(\mathrm{m} / \mathrm{s}^{2}\right) \text { at } \\
\text { V5 } \mathrm{km} / \mathrm{hr}\end{array}$ & $\begin{array}{l}\text { Body vertical } \\
\text { acceleration }\left(\mathrm{m} / \mathrm{s}^{2}\right) \text { at } \\
\text { V } 7.5 \mathrm{~km} / \mathrm{hr}\end{array}$ \\
\hline Air ( Nitrogen zero\% ) & 0.037789 & 0.037788 & 0.037324 \\
\hline Nitrogen 25\% & 0.037441 & 0.037441 & 0.037473 \\
\hline Nitrogen 50\% & 0.037802 & 0.037802 & 0.038143 \\
\hline Nitrogen $75 \%$ & 0.037318 & 0.037318 & 0.038084 \\
\hline Nitrogen $100 \%$ & 0.037015 & 0.037500 & 0.036670 \\
\hline
\end{tabular}

Figure - 18. shows the effect of the tire inflation pressure on the ride comfort at tire speed of $2.5 \mathrm{~km} / \mathrm{hr}$ and sprung mass weight of $480 \mathrm{~kg}$. pressure 55 psi with speed hump (i.e. $\mathrm{h}=50$ ), it can be seen that the RMS value of the body acceleration is decreased when used Nitrogen 25\% - $0.92 \%$ when the tire inflation is changed from Nitrogen 50\%, the body acceleration is decreased by $-0.04 \%$ when the tire inflation is changed from Nitrogen $75 \%$, the body acceleration is decreased by $-1.25 \%$ when the tire inflation is changed from Nitrogen $100 \%$ the body acceleration is decreased by - $2 \%$ At tire speed of $5 \mathrm{~km} / \mathrm{hr}$ and sprung mass weight of $480 \mathrm{~kg}$. . pressure 55 psi with speed hump (i.e. $\mathrm{h}=50$ ), it can be seen that the RMS value of the body acceleration is decreased when used Nitrogen 25\% - $0.92 \%$ when the tire inflation is changed from Nitrogen 50\%, the body acceleration is decreases by $-0.04 \%$ when the tire inflation is changed from Nitrogen $75 \%$, the body acceleration is decreased by $-1.25 \%$ when the tire inflation is changed from Nitrogen $100 \%$ the body acceleration is decreases by $-0.8 \%$ at tire speed of $7.5 \mathrm{~km} / \mathrm{hr}$ and sprung mass weight of $480 \mathrm{~kg}$. pressure $55 \mathrm{psi}$ with speed hump (i.e. $\mathrm{h}=0$ ), it can be seen that the RMS value of the body acceleration is increased when used Nitrogen $25 \% 0.4$ $\%$ when the tire inflation is changed from Nitrogen 50\%, the body acceleration is increased by $2.2 \%$ when the tire inflation is changed from Nitrogen $75 \%$, the body acceleration is increased by 2. \% when the tire inflation is changed from Nitrogen $100 \%$ the body acceleration is decreases by $-1.8 \%$

\section{RESULTS AND DISCUSSION}

All the results obtained from testing the tires under various conditions, clearly prove that nitrogen filling in vehicle tires can reduce rolling resistance. As a result of reduction in rolling resistance, the tire wear is reduced, its life increases and improves the fuel efficiency of the vehicle. The phenomenon of nitrogen uses as an alternative to air in vehicle tires without any definite information about this phenomenon. The experimental results showed that, When the pressure was reduced air use was better than nitrogen, especially at high speeds, it is also noted that the using nitrogen in the tire for air the vehicle vibration without speed hump. 
- When the pressure was reduced by about $10 \%$, at $50 \mathrm{psi}, 400 \mathrm{~kg}$, From V2.5 Km / decreases form - $1.5 \%$ It is also noted that by increasing the tire speed from V5 Km / hr the vehicle vibrations increased form $3.5 \%$. by increasing the tire speed from V7.5 Km / hr It is also noted that the vibrations increased form $1.8 \%$

- The experimental results indicated also that, with speed hump from $\mathrm{V} 2.5 \mathrm{Km} / \mathrm{hr}$ using the nitrogen in the tire for air the vehicle vibration is decreased by $-0.5 \%$ It is also noted that by increasing the tire speed from V5 Km / hr. the vehicle vibrations increased form $2.8 \%$. by increasing the tire speed from $\mathrm{V} 7.5 \mathrm{Km} / \mathrm{hr}$. It is also noted that the vibrations increased form $2 \%$

The experimental results indicated also that. When the weight was increased to $480 \mathrm{~kg}$, with speed hump, the results for air and nitrogen close to each other

- $\quad$ The results indicated that at tire pressure 55 psi, Weight 400, without speed hump from V2.5 $\mathrm{Km} / \mathrm{hr}$ using the nitrogen in the tire for air the vehicle vibration decreases form - $0.75 \%$ It is also noted that by increasing the tire speed from V5 Km / $\mathrm{hr}$ the vehicle vibrations decreased form $-1 \%$ by increasing the tire speed from $\mathrm{V} 7.5 \mathrm{Km} / \mathrm{hr}$ It is also noted that the vibrations decreased form $-1.2 \%$

- $\quad$ The results also indicated by increasing the weight from $480 \mathrm{Kg}$ at tire pressure 55 psi, without speed hump from V2.5 $\mathrm{Km} / \mathrm{hr}$ using the nitrogen in the tire for air the vehicle vibration decreases form $-1.52 \%$ It is also noted that by increasing the tire speed from V5 Km / hr the vehicle vibrations decreased form $-1.5 \%$. by increasing the tire speed from V7.5 Km / hr It is also noted that the vibrations decreased form $-2.2 \%$

- The increase of the pressure about $10 \%$, at $60 \mathrm{psi}, 400 \mathrm{~kg}$, air use was better than nitrogen, especially at high speeds,

- By increasing the weight to $480 \mathrm{~kg}$, without speed hump the using nitrogen in the tire for air, the vehicle vibration from $\mathrm{V} 2.5 \mathrm{Km} / \mathrm{hr}$ decreases form - 1.33\% It is also noted that by increasing the tire speed from V5 Km / hr the vehicle vibrations decrease form $-1.23 \%$. by increasing the tire speed from $\mathrm{V} 7.5 \mathrm{Km} / \mathrm{hr}$ It is also noted that the vibrations decrease form $-1.5 \%$

The experimental results showed that. with speed hump from $\mathrm{V} 2.5 \mathrm{Km} / \mathrm{hr}$ using the nitrogen in the tire for air the vehicle vibration decreases form $-1 \%$ It is also noted that by increasing the tire speed from V5 $\mathrm{Km} / \mathrm{hr}$ the vehicle vibrations decreases form $-1.12 \%$ by increasing the tire speed from $\mathrm{V} 7.5 \mathrm{Km} / \mathrm{hr}$ It is also noted that the vibrations decreases form $-2 \%$.

\section{CONCLUSION}

The effect of the use of nitrogen in tires on the comfort of the ride were discussed through the effect of nitrogen inflation on vehicle tires and the benefits of nitrogen use, the effect of the use of nitrogen in tires on passenger comfort. And the results showed improved ride comfort with the use of nitrogen in the tires, especially with the ideal pressure of the tire and when increasing load and high speed in simple proportions, but better than the use of air, and this gives preference to the generalization of the use of nitrogen tires automotive.

\section{REFERENCES}

[1] Modern Automotive Technology, James E. Duffy, the Good heart- Willcox Company, Inc., Tinly Park, Illinois.

[2] The Automotive Chassis, Dipl Ing and Jensen Reimpell, Butterworth HeinemannInc, MA 01801-2041.

[3] Trans-Consult (Dick Fischer) " Tire information " 2013

[4] Clemson University "Effect of nitrogen filing on tire rolling resistance and vehicle fuel economy " Prakash Venkataraman December 2007.

[5] The Yokohama Rubber Co., Ltd" Yokohama off-the-road tires handbook 2013

[6] John W. Daws "Practical Aspects of Nitrogen Tire Inflation" 2010

[7] Pacific Grove, CA "Why Inflating Tires with Nitrogen Makes Sense” 2005.

[8] Parker Hannifin Corporation "Nitrogen Tire Inflation Systems" 2006

[9] John W. Daws "Nitrogen Tire Inflation: When Does the Tire Really Need it" 2012

[10] Walter H. Waddell "Evaluation of nitrogen inflation of tires" Beijing University of Chemical Technology Beijing, China 2013.

[11] Bridgestone, "Should you stop putting air in your tires" Bridgestone/ Firestone North American Tire, 2003.

[12] Mr. Gil Schoener “Air Products and Chemicals” November 18, 2004.

[13] Luca sabino "Inflation with de-oxygenated"1999,2000.

[14] The Honorable Byron L. Dorgan United States Senate "Underinflated Tires in the United States" February 9, 2007

[15] John M. B, David R. B, and Kevin R. E "Effects of Nitrogen Inflation on Tire Aging and Performance" Ford Motor Company Dearborn, MI 2004.

[16] Konrad Mech, P. Eng. MBA “Why Nitrogen Tire Inflation Extends Commercial Tire Tread Life” Drexan Corporation 2005 
[17] John W. Daws, Ph.D., P.E. "Nitrogen Inflation for Passenger Car and Light Truck Tires” Daw Engineering, LLC 2010.

[18] National Highway Traffic Safety Administration "The Effects of Varying the Levels of Nitrogen in the Inflation Gas of Tires on Laboratory Test Performance. "2009

[19] Samuel S. Graham "Nitrogen tire inflation system and method" United States Patent, p11, 2012.

[20] Prakash venkataraman "Effect of nitrogen filling on tire rolling resistance and vehicle fuel economy" Clemson University, MSC,2007.

[21 [23] Nader Jalili, Ph.D. “Tire nitrogen filling” Clemson University, Clemson, South Carolina, 2006

[22] Miss.P.Y. Mhaske, Prof. P.A. Narwade, Prof. M.P. Nagarkar "Stiffness analysis of passenger car tire using Nitrogen" Maharashtra, India 2016.

[23] Toyo tire talk "Nitrogen Gas Inflation” Technical Service Department Japan, 2005

[24] Bridgestone/ Firestone North American Tire "Should you stop putting air in your tires", 2003

[25] M. Demicd and J. Lukicd "Some Aspects of the investigation of Random Vibration Influence On Ride Comfort"2001. [26] Dr. Aref Ali and Dr. Yasser Hassan "Studying of the dynamic model of the suspension system in vehicles andits movement flexibility" 2013

[27] Hassan Nahvi1, Mohammad Hosseini Fouladi \& Mohd Jailani Mohd " Evaluation of whole -body vibration and ride comfort in a passenger car "2009 